\title{
The role of nickel allergy in hand dermatitis and its impact on handling cupronickel currency coins. A comparative cohort study from Kuwait
}

\author{
Nawaf Almutairi ${ }^{1,2}$, Fahad Almutawa ${ }^{1}$ \\ 'Department of Medicine, Faculty of Medicine, Kuwait University, Kuwait \\ ${ }^{2}$ Department of Dermatology, Farwaniya Hospital, Kuwait
}

Adv Dermatol Allergol 2017; XXXIV (4): 313-321

DOI: https://doi.org/10.5114/ada.2017.69309

\begin{abstract}
Introduction: Contact with nickel-releasing coins as a cause of hand dermatitis has been debated.

Aim: Studying a hand dermatitis risk from handling Kuwaiti cupronickel coins among nickel-allergic and nickel non-allergic subjects.

Material and methods: One hundred hand dermatitis patients (group I: nickel-allergic) and 100 matched patients (group II: nickel non-allergic) were selected from over 500 hand dermatitis cases seen between September 2014 and September 2015. Nickel released from Kuwaiti cupronickel coins immersed in a standardized artificial sweat solution was measured at 1, 24, 48, 144 and $168 \mathrm{~h}$ at room temperature. Subjects in both groups were exposed to nickel releasing coins. The process was repeated after 3 months using nickel coated coins as controls.

Results: Nickel released from 20, 50 and 100 fils Kuwaiti cupronickel coins at 1 week was 28.64, 32.76, 35.76 $\mu \mathrm{g} / \mathrm{cm}^{2} /$ week, respectively. Ninety-one patients (29 males, 62 females) in group I and 87 patients (38 males, 49 females) in group II completed the study. $47.3 \%$ in group I vs. $13.8 \%$ in group II developed dermatitis on exposure to nickel releasing coins. Nickel coated coins resulted in dermatitis in $8.8 \%$ of group I vs. $5.7 \%$ in group II.

Conclusions: Nickel is released significantly from cupronickel Kuwaiti coins. Handling of coins caused dermatitis more often in patients with nickel-allergy compared to nickel non-allergic patients.
\end{abstract}

Key words: Kuwaiti cupronickel coins, hand dermatitis, nickel allergy.

\section{Introduction}

Contact allergy is an important public health problem with a significant personal, social and economic impact on the affected individuals, and the society at large. Nickel exposure is the most common cause of contact allergy in the general population. Also, nickel allergy is a wellknown risk factor for developing hand eczema [1, 2]. Common sources of nickel allergy are jewelry and other metal items coming in contact with the skin such as belt buckles, watches, clothing metal items such as buttons, clips, hooks, buckles, clippers, etc. Skin contact with any item that releases nickel in sufficient amounts may cause contact allergy and dermatitis, as shown recently by the increasing use of metallic mobile phones and laptop computers [3]. One study from Sweden showed that the prevalence of nickel allergy in students aged 15-23 years was $13 \%$ in females and $2.5 \%$ in males [4], and that $24 \%$ of female and $7.4 \%$ of male dermatitis patients were allergic to nickel [5]. However, a more recent study from Sweden shows a decreasing prevalence of nickel allergy especially in young women [6]. And, a reduction in prevalence of nickel allergy has also been seen in other EU states like in Denmark, Germany and Italy [7]. The decrease in prevalence has been largely due to stricter EU norms for regulation of nickel content in REACH items. Wherein, the items intended for prolonged contact with the skin are not allowed to release nickel at a rate $>0.5 \mu \mathrm{g} /$ $\mathrm{cm}^{2} /$ week. Allergic nickel dermatitis still remains a problem in EU nations. This might be attributable to lack of restrictions on many short and frequent contacts with everyday items and products containing nickel, such as coins and tools [8]. Some of those items in the work tools and materials may release nickel in high amounts [9]. Occupations requiring short and repeated contact with nickel and involving tools and objects such as cashiers,

Address for correspondence: Prof. Nawaf Almutairi MD, PhD, Department of Medicine, Faculty of Medicine, Kuwait University, P.O. Box 280, Farwaniya 80000, Kuwait, phone: +965-99370203, fax: +965-24808167, e-mail: nalmut@usa.net Received: 4.04.2016, accepted: 15.05.2016. 
sales assistants, hairdressers, health care workers, dental assistants etc. are at risk of nickel allergy [10]. This may result in hand eczema, a chronic condition that can result in poor quality of life, reduced ability to work, and large costs to individuals and the society [11]. Handling of nickel containing coins may be a potential contributor to occurrence or aggravation of signs and symptoms of dermatitis in nickel sensitized individuals [12].

\section{Aim}

Many studies have been reported, mainly from Europe, on the risk of allergic dermatitis from handling coins and its various aspects $[13,14]$. No such study has been conducted in Kuwait or the Middle East. However, cupronickel coins have been in use since 1961 in Kuwait. This prompted us to conduct the present study.

\section{Material and methods}

All patients diagnosed in the past with hand dermatitis presenting to the dermatology departments of two tertiary level government hospitals, in two different governorates in Kuwait between September 2014 and September 2015 (1 year duration) were enrolled. The study was approved by ethics committees of the respective hospitals. All the recruited patients had given written informed consent to participate in the study, and also to undergo patch tests and coin handling tests in spite of being made aware of a remote chance of sensitization in few of non-sensitized patients. All the recruited patients who were found eligible and were all screened for nickel allergy. The screening was done by patch tests using European baseline series (Chemotechnique Diagnostics ${ }^{\mathrm{TM}}$, Velling, Sweden) with nickel sulphate (5\% petrolatum) within IQ chambers (Chemotechnique Diagnostics TM, Velling, Sweden). A total of 500 patients underwent patch testing during the study period. Of these, $100 \mathrm{pa}$ tients with positive patch tests (group I: nickel-allergic,) and 100 matched patients with negative patch tests to nickel (group II: nickel non-allergic) were included for further testing with coin handling. A detailed clinical, occupational, exposure history and clinical examination was conducted and recorded in a performa. Ninety-one patients from group I (29 males, 62 females) and 87 from group II (38 males, 49 females) completed the study and were available for analysis.

\section{Exclusion criteria}

- Subjects with hand dermatitis exacerbation at the time of the procedure.

- Subjects with severe reactions in the patch test (angry back).

- Pregnancy and lactation.

- Subjects on immunosuppressive medications.

\section{Special instructions}

Patients were advised to refrain from wearing any nickel-containing clothes or articles (watches, zips, artificial jewelry, medals etc.) for 1 week prior to the date of exposure to nickel-releasing coins until the completion of the second phase of the study (i.e. exposure to nickel coated coins 3 months later). Handling of Kuwaiti coins in a day-to-day life was allowed.

Every patient was provided with a nickel spot test kit (CHEMO-NICKEL TEST ${ }^{\oplus}$, Chemotechnique Diagnostics AB, Malmo, Sweden) to facilitate identifying nickel-containing metals (to reduce prolonged and direct contact with higher nickel-releasing items).

The same subjects served as controls in each group after 3 months. We repeated the same steps with them but with coated nickel coins.

\section{Specifications of the Kuwaiti coins}

Kuwaiti coins 100 fils, 50 fils and 20 fils are made from cupronickel alloy (one Kuwaiti dinar is 1000 fils). The specification of these coins is shown in Table 1 [15].

\section{Preparation of coins}

Nickel releasing coins: The coins were in circulation and not cleaned or pretreated prior to use by the subjects. This was done to ensure that study conditions were kept as close as possible to the real life situation.

Non-nickel releasing coins (control coated nickel coins): The same nickel releasing coins used in the first stage of the study were coated with transparent nitrocellulose lacquer (free of formaldehyde, toluene, or dibutyl phthalate). Each coin received three coats of the nitrocellulose coats.

Table 1. Specifications of Kuwaiti cupronickel coins of different denominations

\begin{tabular}{|c|c|c|c|c|c|}
\hline Denomination & Standard composition & $\begin{array}{l}\text { Diameter } \\
{[\mathrm{mm}]}\end{array}$ & $\begin{array}{c}\text { Gross weight } \\
\text { [g] }\end{array}$ & $\begin{array}{c}\text { Years in } \\
\text { circulation }\end{array}$ & $\begin{array}{c}\text { Surface area } \\
{\left[\mathrm{mm}^{2}\right]}\end{array}$ \\
\hline 100 fils & 75\% copper, 25\% nickel & 26 & 6.50 & $1962-2014$ & 530.66 \\
\hline 50 fils & $75 \%$ copper, $25 \%$ nickel & 23 & 4.50 & 1962-2014 & 415.26 \\
\hline 20 fils & 75\% copper, $25 \%$ nickel & 20 & 3.00 & $1962-2013$ & 314 \\
\hline
\end{tabular}

KM number: KM stands for Krause and Mishler, the original authors of the Standard Catalog of World Coins. 
These coated coins were then tested with dimethylglyoxime (DMG) nickel spot test each day before running the test to ensure the efficiency of the coating in preventing the release of nickel from the coins onto the skin. Any coin that gave positive reaction to the DMG test was replaced by another coated and tested coin. We did the same procedure at the end of the day to test if there was no nickel release.

\section{Patch testing}

European baseline series (Chemotechnique Diagnostics $^{\top M}$, Velling, Sweden) with nickel sulphate (5\% petrolatum) within IQ chambers (Chemotechnique Diagnostics TM, Velling, Sweden). Nickel sulfate hexahydrate (purity $\geq 98.5 \%$ ) is used in this patch. The patch was applied to the upper back for $48 \mathrm{~h}$, and read at $48 \mathrm{~h}, 72 \mathrm{~h}$ and $96 \mathrm{~h}$. Nickel positivity was defined as revealing erythema and/ or edema at $96 \mathrm{~h}$ utilizing the standard International Contact Dermatitis Research Group Criteria (ICDRG) [16].

\section{Determining nickel release from the coins}

The amount of nickel released from the Kuwaiti cupronickel coins was determined using the standard method according to EN1811 (EU Nickel Directive), by immersing in an artificial sweat solution for 1 week [9]. Kuwaiti cupronickel coins of 100 fils, 50 fils and 20 fils denominations obtained from the circulated coins issued by the Central Bank of Kuwait were used for the study. An artificial sweat solution was prepared as per the EN1811 (EU Nickel Directive) resulting in the desired composition (0.5 wt \% sodium chloride, 0.1 wt \% lactic acid, 0.1 wt \% urea) and normal ultra pure water (not aerated as described in the standard) [17]. The $\mathrm{pH}$ of the solution was adjusted to $\mathrm{pH} 6.5$ using the ammonium hydroxide solution. An artificial sweat solution was stored in darkness and used within $3 \mathrm{~h}$ of preparation. The $\mathrm{pH}$ was measured before and after immersion.

\section{Reagents and instruments}

A Hitachi Model 180-50 atomic absorption spectrometer (Hitachi Ltd., Tokyo, Japan) equipped with a Hitachi GA-3 graphite furnace atomizer, Tristar grade nitric acid (BDH laboratory supplies, Poole, UK), Milli-Q ultra pure water (18 M $\Omega \mathrm{cm}$; Millipore, Watford, UK), Graduated sample tubes (10 ml; Saestedt AG, Nurnbrecht, Germany) were used throughout the study.

The coins were placed in $10 \mathrm{ml}$ of a freshly prepared artificial sweat solution in a $10 \mathrm{ml}$ volumetric flask. One milliliter of the solution served as a blank. The samples were shaken at $200 \mathrm{rpm}$ in a bath at $37^{\circ} \mathrm{C}$ for 1 week. Successive $1 \mathrm{ml}$ samples were removed daily and nitric acid $1 \%$ was added to each sample to stabilize the extracted nickel. The samples were then stored in a glass vial in a refrigerator until analysis. The quantity of nickel released was analyzed by the atomic absorption spectrometer. The nickel concen- tration in the solution was calculated at 1, 24, 72, 48, 96, 120,144 , and $168 \mathrm{~h}$ at room temperature. Triplicate readings of each sample were carried out. Nickel results were based on the average concentration measure. The results for all the samples were blank corrected by subtracting the average value of the three corresponding blanks. The amount of nickel released per area unit was calculated and was expressed in $\mu \mathrm{g} / \mathrm{cm}^{2}$.

\section{Metal analysis}

Chemical analysis of nickel was performed with flame atomic absorption spectrometry in our laboratory. Standard solutions containing $0.1,1,10,50,100$ and $500 \mu \mathrm{g} / \mathrm{l}$ in $1 \% \mathrm{HNO}_{3}$ were used for calibration.

\section{Coin handling criteria}

Kuwaiti cupronickel coins of 20 fils, 50 fils and 100 fils denominations were kept immersed in the prepared artificial sweat solution in a clean 1-liter glass container for $30 \mathrm{~min}$.

At the beginning of the test the nickel releasing coins were placed in container $A$.

Step (1): All the subjects (in the two groups) were asked to wet their hands with the artificial sweat solution once directly before handling the coins.

Step (2): Each subject was instructed to pick 60 coins (20 of each denomination of 100 fils, 50 fils and 20 fils) from the container marked (A) containing 120 coins of each denomination, transfer them one by one to another empty container marked (B) in 5 min. These steps were repeated every $5 \mathrm{~min}$ for $30 \mathrm{~min}$. At the end of the $30 \mathrm{~min}$, all the coins in bowl (A) were transferred to bowl (B).

Step (2) was carried out 2 times a day for 7 days, $9 \mathrm{~h}$ apart (at 9 am and $6 \mathrm{pm}$ ).

Step (3): The same procedure was repeated after 3 months for both groups with non-nickel release coins. The subjects were followed for 3 weeks after handling the coins (2 visits every week) for recording the results. We did not do DMG test of the patients' hands following the study.

\section{Clinical scoring for signs of dermatitis [18]}

Erythema: was graded from 0 to $5 ; 0=$ no reaction; 1 = weak spotty or diffuse erythema; 2 = weak but wellperceptible erythema covering the total exposure area; 3 = moderate erythema; 4 = severe erythema with edema or palpable infiltration; 5 = very severe erythema with epidermal defects (vesicles, erosions, pustules or bulla formation).

Vesicles: The number of vesicles (including intact and more advanced broken vesicles) on the exposed areas was recorded on a semi-quantitative scale and was graded from 0 to 6 ( $0=$ no vesicles; $1=1-10$ vesicles; $2=$ $11-20$ vesicles; $3=21-30$ vesicles; $4=31-40$ vesicles; $5=$ $41-50$ vesicles; $6=>50$ vesicles). 
The individual vesicles were counted under a magnifying lamp. Scaling: was recorded as existent (1) or not existent (0). Itching: Graded as $0=$ no itching, $1=$ mild itching, 2 = moderate itching, 3 = severe itching.

\section{Statistical analysis}

The computer program SPSS (Chicago, IL, USA) was utilized for the statistical analysis. The Wilcoxon signed rank test or the Mann-Whitney rank sum test was performed for intra individual comparisons and between both the groups, respectively.

\section{Results}

\section{Nickel release from Kuwaiti cupronickel coins}

The amounts of nickel released from the coins in the artificial sweat solution at different intervals from $1 \mathrm{~h}$ to $168 \mathrm{~h}$ are depicted in Figure 1. Nickel was detected in all extracts, but the amount increased significantly with duration of immersion in the artificial sweat solution. The maximum amount of nickel released at 1 week was 35.15 $\mathrm{\mu g} / \mathrm{cm}^{2} /$ week from 100 fil coins and the minimum (28.64 $\mu \mathrm{g} / \mathrm{cm}^{2} /$ week) was from 20 fil coins.

Mean \pm SD of age (years), sex and occupation distribution of patients finally analyzed in both groups are shown in Table 2.

\section{Skin exposure to nickel by coin handling in both groups}

Incidence of dermatitis in both groups after handling of nickel releasing coins is shown in Table 3. It showed that $52.7 \%$ of nickel sensitized patients (group I) did not develop any dermatitis during the study period. Thirty-three (36.3\%) patients (7 males, 26 females) developed mild to moderate dermatitis, while 10 (11\%) patients (4 males, 6 females) developed severe hand dermatitis during the

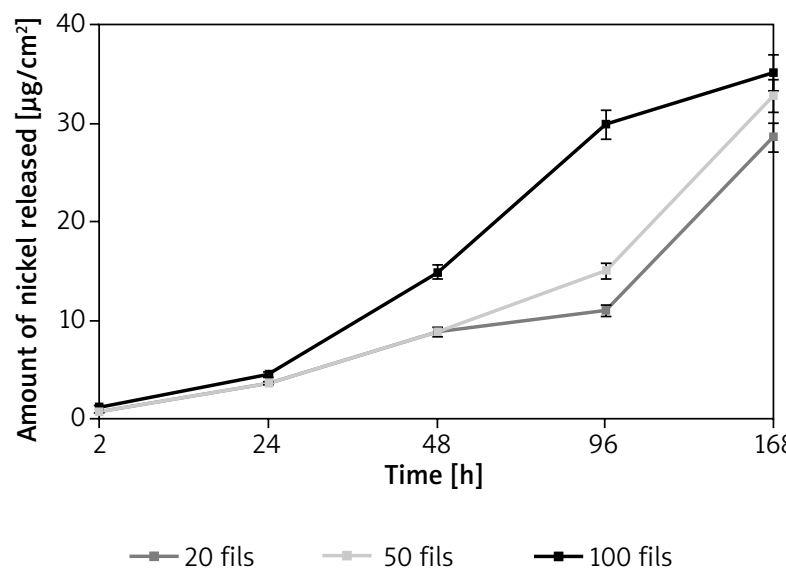

Figure 1. Average amount of nickel released from 100 fils, 50 fils, 20 fils Kuwaiti cupronickel coins with time observation period. In contrast, only 9 (10.4\%) patients (4 males, 5 females) had mild to moderate and 3 (3.4\%) patients (2 males, 1 females) from group II got severe dermatitis in the first phase of the study. A vast majority of 75 (86.5\%) patients in group II did not develop any dermatitis after handling the nickel releasing coins. Out of these 9 patients with positive reactions, 2 ( 1 male, 1 female) showed nickel positive reaction on the repeat patch test.

Incidence of hand dermatitis dropped drastically in both groups after exposure to coated nickel coins (Tables 4 and 5). Six (6.66\%) patients (2 males, 4 females) developed mild to moderate, whereas only 2 patients (1 male, 1 female) developed severe hand dermatitis among group I patients in the second phase of the study. Only 5 (5.7\%) patients ( 2 males, 3 females) had dermatitis of mild to moderate severity after exposure to nickel coated coins among the group II subjects. No subject from group II had severe dermatitis.

Dermatitis in almost all the patients was noticed within 7 days of coin handling tests. The patients were given only systemic antihistamines to relieve pruritus, during all 7 days of coin handling. Thereafter, emollients and mid potency topical steroids were added. Systemic steroids for short duration were used in severe cases, and only after interpretation of results of repeat patch tests had been done.

\section{Discussion}

\section{Nickel allergy}

Nickel is one of the most common allergen causing contact dermatitis [19]. The prevalence of nickel allergy in the general population is estimated around $10 \%$, and it still remains the most common cause of contact allergy worldwide. Females are affected more commonly (10\%) compared to males (2\%). Contact with jewelry and skin piercing are the probable contributory factors of this dif-

Table 2. Age, sex and occupation distribution of patients

\begin{tabular}{lcc}
\hline Parameter & $\begin{array}{c}\text { Group 1 } \\
n=91\end{array}$ & $\begin{array}{c}\text { Group II } \\
n=87\end{array}$ \\
\hline Males & $29(31.9 \%)$ & $34(39.1 \%)$ \\
\hline Females & $62(68.1 \%)$ & $53(60.9 \%)$ \\
\hline $\begin{array}{l}\text { Age, range (mean } \pm \text { SD) } \\
\text { [years] }\end{array}$ & $\begin{array}{c}17-61 \\
(40 \pm 6.8)\end{array}$ & $\begin{array}{c}21-58 \\
(35 \pm 5.3)\end{array}$ \\
\hline Cashiers & 12 & 5 \\
\hline Health care workers & 15 & 12 \\
\hline Clerks/office workers & 14 & 26 \\
\hline Hairdressers & 16 & 18 \\
\hline Housewives & 12 & 16 \\
\hline Factory workers & 12 & 6 \\
\hline Construction workers & 10 & \\
\hline
\end{tabular}


Table 3. Incidence of hand dermatitis after exposure to nickel releasing coins at the beginning of the study in both groups

\begin{tabular}{|c|c|c|c|c|c|c|}
\hline \multirow[t]{3}{*}{ Variable } & \multicolumn{6}{|c|}{ Nickel patch test } \\
\hline & \multicolumn{3}{|c|}{$\begin{array}{l}\text { Positive patients } \\
\text { Group I }(n=91)\end{array}$} & \multicolumn{3}{|c|}{$\begin{array}{l}\text { Negative patients } \\
\text { Group II }(n=87)\end{array}$} \\
\hline & $\begin{array}{l}\text { Males } \\
n=29\end{array}$ & $\begin{array}{c}\text { Females } \\
n=62\end{array}$ & $\begin{array}{c}\text { Total } \\
n=91\end{array}$ & $\begin{array}{l}\text { Males } \\
n=38\end{array}$ & $\begin{array}{l}\text { Females } \\
n=49\end{array}$ & $\begin{array}{c}\text { Total } \\
n=87\end{array}$ \\
\hline No dermatitis & $18(19.8 \%)$ & $30(32.9 \%)$ & $48(52.7 \%)$ & $32(36.8 \%)$ & $43(49.4 \%)$ & $75(86.2 \%)$ \\
\hline Mild to moderate dermatitis & $7(7.7 \%)$ & $26(28.6 \%)$ & $33(36.3 \%)$ & $4(4.7 \%)$ & $5(5.7 \%)$ & $9(10.4 \%)$ \\
\hline Severe dermatitis & $4(4.4 \%)$ & $6(6.6 \%)$ & $10(11 \%)$ & $2(2.3 \%)$ & $1(1.1 \%)$ & $3(3.4 \%)$ \\
\hline
\end{tabular}

Table 4. Incidence of hand dermatitis after exposure to non-nickel releasing coins in the second stage of the study at 3-months interval

\begin{tabular}{lcccccc}
\hline Variable & \multicolumn{3}{c}{ Nickel patch test } \\
\cline { 2 - 7 } & \multicolumn{3}{c}{$\begin{array}{c}\text { Positive patients } \\
\text { Group I }(n=91)\end{array}$} & \multicolumn{3}{c}{$\begin{array}{c}\text { Negative patients } \\
\text { Group II }(n=87)\end{array}$} \\
\cline { 2 - 7 } & Males & $\begin{array}{c}\text { Females } \\
n=68\end{array}$ & $\begin{array}{c}\text { Total } \\
n=91\end{array}$ & $\begin{array}{c}\text { Males } \\
n=38\end{array}$ & $\begin{array}{c}\text { Females } \\
n=49\end{array}$ & $\begin{array}{c}\text { Total } \\
n=87\end{array}$ \\
\hline No dermatitis & $26(28.6 \%)$ & $57(62.6 \%)$ & $83(91.2 \%)$ & $36(41.4 \%)$ & $46(52.9 \%)$ & $82(94.3 \%)$ \\
\hline Mild to moderate dermatitis & $2(2.2 \%)$ & $4(4.4 \%)$ & $6(6.6 \%)$ & $2(2.3 \%)$ & $3(3.4 \%)$ & $5(5.7 \%)$ \\
\hline Severe dermatitis & $1(1.1 \%)$ & $1(1.1 \%)$ & $2(2.2 \%)$ & 0 & 0 & 0 \\
\hline
\end{tabular}

Table 5. Overall incidence of hand dermatitis in phase I (exposure to nickel releasing coins) and phase II (exposure to non-nickel releasing coins) in both groups

\begin{tabular}{lcccc}
\hline Variable & \multicolumn{3}{c}{ Nickel Patch Test } \\
\cline { 2 - 5 } & \multicolumn{2}{c}{$\begin{array}{c}\text { Positive patients } \\
\text { Group I }\end{array}$} & \multicolumn{2}{c}{$\begin{array}{c}\text { Negative patients } \\
\text { Group II }\end{array}$} \\
\cline { 2 - 5 } & Phase I & Phase II & Phase I & Phase II \\
\hline No dermatitis & $48(52.7 \%)$ & $83(91.2 \%)$ & $75(86.2 \%)$ & $82(94.3 \%)$ \\
\hline Mild to moderate dermatitis & $33(36.3 \%)$ & $6(6.6 \%)$ & $9(10.4 \%)$ & $5(5.7 \%)$ \\
\hline Severe dermatitis & $10(11 \%)$ & $2(2.2 \%)$ & $3(3.4 \%)$ & 0 \\
\hline
\end{tabular}

ference seen among females and males. Atopy increases the risk of nickel sensitization [20].

Common sources of nickel exposure to skin are jewelry, metal elements on clothing and apparels, belt buckles and wrist watches. Certain occupations also expose people to nickel at higher amounts, repeatedly and for prolonged duration thus posing a risk. These include nickel industry workers, electroplaters, electronic and general assemblers, saloon workers (beauticians, hairdressers), health care assistants, dental assistants, cooks and caterers [21].

\section{Coin handling and nickel allergy}

With the enactment of restrictive laws in most of the developed nations, the prevalence of nickel allergy has seen a downward trend especially in young females [7]. But, these laws still do not cover the causes of nickel al- lergy due to repetitive and short exposure to nickel for example as seen in coin handlers, like cashiers [8]. Hence, recently lot of attention has been paid to nickel releasing coins as a source of nickel allergy and dermatitis among certain occupations [22]. Nickel is used in making coins because the metal has excellent beneficial attributes such as low cost, shiny surface, sufficient weight, high corrosion resistance, recyclable and easy to stamp [23]. Coins of various denominations are used in almost all the countries for daily monetary transactions at various points of sales, trading and banking. Majority of the coins being used in most of the countries contain nickel or nickel alloys. In fact copper-nickel was the most frequently identified coin alloy (102; 28\%) followed by aluminum-bronze (62; 17\%). Amongst 361 denominations from 52 countries representing $75 \%$ of the world 
population, 239/835 (28\%) released nickel. In some countries, more than one third of the denominations released nickel (US, Japan, Russia, Mexico). They released nickel at significant levels [24]. Cashiers and sales assistants comprise a special group of people, who may be exposed to large amounts of nickel from prolonged and repeated handling of metal coins because of the nature of their jobs. The role of handling coins in causing and aggravating dermatitis has been debated for long in the past [25]. According to Fisher [25], handling of coins in routine daily life causes insufficient exposure to skin so as to cause allergy and symptoms. A thick horny layer of the skin over palms may also protect. However, of late, consensus is emerging that handling of nickel releasing coins is a potential source of nickel sensitization and allergy [26].

The role of nickel exposure from coins as a contributor to causation or flare ups of signs and symptoms of nickel allergy and nickel hand dermatitis has also been questioned by the nickel coins producers, and some dermatologists. However, several elegant studies have demonstrated that nickel is released from the coins in significant amounts [27]. A significant amount of released nickel is thus deposited onto the skin, with small interindividual variation, by handling of the coins in daily life. Therefore, coin handling is likely to play a role in nickel sensitization and dermatitis [28].

\section{Nickel exposure and hand dermatitis}

There are data to suggest that significant aggravation of hand dermatitis occurs, when patients with nickel allergy and ongoing mild to moderate hand dermatitis were exposed to nickel $10 \mathrm{~min} /$ day for 2 weeks [29]. The levels of nickel deposited may be sufficient to induce dermatitis in a significant number of nickel sensitized patients [30, 31]. The authors of these studies have concluded that nickel releasing coins pose a health hazard to nickel sensitized persons especially those engaged in occupations exposing them to repeated and prolonged contact with such coins. The amount of nickel released depends on the size, surface area, content and type of the coins. Accordingly, Nucera et al. [31] had concluded that new euro coins may be more dangerous than old Italian lira.

Julander et al. [14] in their recent study of newly introduced nickel-plated steel coins in the UK found that the amount of nickel deposited onto the skin during the handling of these coins for $1 \mathrm{~h}\left(7.5 \mu \mathrm{g} / \mathrm{cm}^{2}\right)$ was four times higher than that from cupronickel coins. Initial nickel release rates were 10-27 times higher than 1-week rates, emphasizing that brief and repeated contact results in significant nickel exposure. They concluded that the nickel-plated coins deposit higher levels of nickel onto the skin than cupronickel coins, and hence pose an increased allergy risk. Furthermore, they suggested that 1-week nickel release in artificial sweat may not be suitable for determining the risk of handling items with high nickel release, and have recommended using nickel skin dose as a measure for risk assessment.

\section{Kuwaiti currency coins and nickel content}

Kuwaiti cupronickel coins of 100 fils, 50 fils and 20 fils denominations have been in circulation since 1961. Other alloy coins such as nickel brass (5 fils; 1961-2011), brass plated steel (5 fils; 2012), stainless steel (20 fils; 2001-2005) had also been in circulation. Nickel-plated steel coins of 100 fils denomination were introduced for 1 year in 2012 to 2013 [15]. The present study showed that nickel is released from Kuwaiti cupronickel coins of 100 fils, 50 fils and 20 fils denominations at high amounts during extraction with artificial sweat. The mean amount of nickel released from Kuwaiti cupronickel coins (100 fils, 50 fils and 20 fils), immersed in artificial sweat for 1 week was $35.15 \mu \mathrm{g} / \mathrm{cm}^{2}, 32.76 \mu \mathrm{g} / \mathrm{cm}^{2}$, and $28.64 \mathrm{\mu g} / \mathrm{cm}^{2}$, respectively. While, the amount released from 2-euro coin was $99 \mu \mathrm{g} / \mathrm{cm}^{2} /$ week [28]. The levels reported earlier were 23-65 $\mathrm{\mu g} / \mathrm{cm}^{2} /$ week [32] and $160 \mu \mathrm{g} /$ $\mathrm{cm}^{2} /$ week [30]. Lower amounts of nickel released seen from Kuwait cupronickel coins may be because of smaller surface areas of Kuwaiti coins in comparison to 2-euro coin (2 euro is $12.2 \mathrm{~cm}^{2}$ and 100 Kuwaiti fils is $5.1 \mathrm{~cm}^{2}$ ).

The EU Nickel Directive states that items that will have direct and prolonged contact with the skin should not release more than $0.5 \mu \mathrm{g}$ of nickel/ $\mathrm{cm}^{2} /$ week, and items for pierced holes not more than $0.2 \mu \mathrm{g} / \mathrm{cm}^{2} /$ week. The amounts released from the cupronickel coins at 1-week are higher than this recommended level. Thus, repeated exposure to even low amounts of nickel, as occurs while handling coins may in fact considerably increase the risk of sensitization and elicitation of dermatitis [8]. This becomes more relevant with recent REACH definition of "prolonged skin contact" with nickel as 10 min on three or more occasions within two weeks or 30 min on one or more occasions within 2 weeks.

The role played by nickel containing coins in causing dermatitis in some patients is clearly brought about in the case report of a nickel-allergic bank clerk who counted coins for half of the workday suffering from dermatitis on the fingers, and later the hands. Vacations and changed work tasks resulted in complete healing. The investigators believed that the patient had been sensitized by coin handling, as she had never reacted to jewelry or other metallic items [21]. In another report, 2 nickel-allergic patients were presented: one developed dermatitis on the nose and the finger from rubbing a coin against the nose when it itched; the other one developed dermatitis on the finger, because he often carried a coin in the finger portion of the glove [25].

It is likely that dermatitis caused by coins is more common outside of Europe, because of the increased risk of sensitization in absence of stricter nickel regulations in day-to-day use items. The accumulation of case reports of nickel dermatitis from coins indicates that 
excessive cutaneous exposure to coins, as seen in cashiers and other occupational groups handling money, may result in nickel sensitization and dermatitis [22, 26]. However, there are some reports to the contrary, where the authors have not found a positive correlation to exposure to nickel coins and occurrence of nickel allergy and dermatitis. Christensen and Moller [33] reported that intense handling of nickel-containing metal objects by patients with nickel contact allergy did not induce visible eczematous activity. Similarly, Zhai et al. [18], in a crossover design study on 18 subjects (10 nickel sensitized and 8 non nickel sensitized) exposed to nickel containing and nickel coated coins, did not find anyone developing allergic contact dermatitis to nickel containing coins. The subjects were asked to handle 10 coins for $5 \mathrm{~min}$ followed by 5 min of rest for $8 \mathrm{~h}$ a day for 12 days in a cross-over design study. Meding and Swanbeck [34] found no significant increase in prevalence of hand eczema in individuals. On the other hand, several cases of nickel coin dermatitis have been reported [8, 18, 22, 26, 35]. Pressure can be an additional contributory factor in nickel dermatitis in sensitized persons [8]. When nickel coins were kept on the palms under occlusion for $24 \mathrm{~h}$, allergic contact dermatitis occurred in nickel-sensitive persons [25].

Nickel skin bioavailability depends on the type of the nickel compound or alloy, vehicle, potential occlusion, skin site and degree of skin inflammation. In particular, a compromised skin barrier may facilitate penetration of nickel and hence greatly increase reactivity [36]. In addition, the amount of nickel released from nickel alloys is a critical factor for nickel dermatitis [37]. Emmett et al. [38] found that the lowest patch test elicitation threshold in a statistically significant number of nickel-sensitive individuals was $1.5 \mu \mathrm{g}$ per patch test. Highly sensitized individuals might react to $0.47 \mathrm{\mu g} / \mathrm{cm}^{2}$ when exposed to inflamed skin under occlusion [38].

In a newly developed 'finger immersion method' to study the amount of nickel deposited in nickel exposed individuals, Staton et al. [29] contended that $2 \mu \mathrm{g} / \mathrm{cm}^{2}$ of nickel may represent 'normal' skin levels. They also found that coin handling induced an appreciable increase in the amount of nickel on the skin within 2 min. Their experiments indicated a linear relationship between coin handling (exposure time) and measured dermal nickel levels following standardized coin handling. A pilot survey, conducted among cashiers, shop assistants, bar staff, hairdressers and workers in the nickel industry revealed dermal nickel concentrations ranging from < 0.9 to $7160 \mathrm{ng} /$ $\mathrm{cm}^{2}$. They found the method to be superior, compared to the acid wipe test and tape stripping in terms of extraction efficiency, speed and ease of operation in the field.

Gawkrodger et al. [39] used the same method to measure the quantities of nickel on the skin of the fingers in workers employed in occupations for which nickel has been suspected as a contact allergen, and to define the threshold for a dermatitis reaction after the single application of a quantity of nickel to the skin of nickelallergic individuals when read at 2 days. They found that nickel levels on the fingers of electroplaters, cashiers, sales assistants, caterers, and even office staff, were at or above $0.035 \mu \mathrm{g} / \mathrm{cm}^{2}$. At these levels, $22 \%$ of nickelallergic subjects will react. This single open application of nickel study demonstrated a dose-response relationship, with no subjects reacting to $\leq 2.5 \mu \mathrm{g} / \mathrm{cm}^{2}$, but increasing numbers reacting at higher concentrations as follows: 6 of $21(28 \%)$ at $5.0 \mu \mathrm{g} / \mathrm{cm}^{2}, 6$ of $19(31 \%)$ at $15 \mu \mathrm{g} / \mathrm{cm}^{2}$, 7 of $19(37 \%)$ at $30 \mu \mathrm{g} / \mathrm{cm}^{2}$ and 11 of 18 (61\%) at $45 \mu \mathrm{g} /$ $\mathrm{cm}^{2}$. The authors concluded that nickel levels on the skin in coin handling occupations and some others are sufficient to induce an allergic contact dermatitis in some nickel-allergic subjects. A single application of $5 \mu \mathrm{g} / \mathrm{cm}^{2}$ when read at 2 days, induced a dermatitis reaction in 6 of 21 nickel-allergic subjects [39].

In our study we found that brief but frequently repeated contact with nickel releasing coins resulted in hand dermatitis in both nickel-allergic (43/91; 47.3\%) group I patients and nickel non-allergic subjects (12/87; 13.8\%). However, in one controlled provocative use test study with nickel-containing coins (Canadian 5 cent coins, $\mathrm{Cu}$ 75\% and Ni 25\%) and nickel-coated coins (Canadian 1 cent coins, Cu $98 \%$ and Zn 2\% or Cu-plated Zn), 18 subjects (10 nickel sensitized and 8 non-nickel sensitized) handled 10 coins (nickel containing coins or nickel-coated coins) in a crossover design at 5 min intervals for $8 \mathrm{~h}$ per day, for a total of 12 days. The authors found that the subjects handling nickel-containing coins daily did not develop allergic contact dermatitis [40]. This can be debated by discussing the following point when interpreting the results: the subjects had normal skin, one hand was protected by a thick cotton glove during coin handling, hands were placed through a heavy fabric hood to prevent coin exposure, and only 10 coins were handled by each subject during 12 days [41]. In our study, only 8 out of 91 (8.8\%) in group I and just 5 (5.7\%) out of 87 of group II developed dermatitis on exposure to nickel non-releasing coins. This could be due to irritation rather than allergic reasons due to repeated exposure to artificial sweat and friction.

Regulations in Europe reducing the permissible amount of nickel release from jewelry and other items have significantly reduced the prevalence of nickel allergy and nickel dermatitis [17, 42, 43]. Similar measures have been advocated in regards to nickel containing coins. Some authors have recommended the use of non-nickel coins to minimize the risk of exposure to nickel, with the aim to reduce the incidence of nickel sensitization and nickel dermatitis [14, 22, 30, 31].

\section{Conclusions}

Nickel is released from Kuwaiti coins of 100 fils, 50 fils and 20 fils denominations in significant amounts. Hand dermatitis was developed in a considerably greater num- 
ber of nickel sensitized patients compared to nickel nonsensitized patients on controlled exposure to these nickel releasing coins. Handling of nickel releasing coins may induce or flare up dermatitis in people exposed repeatedly or for prolonged duration because of the nature of their jobs. Such coins may also induce nickel sensitization among the general population. We support the recommendation that non-nickel releasing coins made of other metal alloys be used for manufacturing coins to minimize the risk of sensitization and dermatitis from nickel.

\section{Acknowledgments}

This work was financially supported by a grant from the Kuwait University (MM013).

Source of funding: KU Grant MM013.

\section{Conflict of interest}

The authors declare no conflict of interest.

\section{References}

1. Lidén C, Bruze M, Menné T. Metals contact dermatitis. In: Contact Dermatitis. $4^{\text {th }}$ edn. Frosch PJ, Menné T, Lepoittevin JP (eds). Springer, Berlin/Heidelberg 2006; 537-68.

2. Wojciechowska M, Czajkowski R, Kowaliszyn B, et al. Analysis of skin patch test results and metalloproteinase-2 levels in a patient with contact dermatitis. Postep Derm Alergol 2015; 32: 154-61.

3. Thyssen JP, Johansen JD, Zachariae C, et al. The outcome of dimethylglyoxime testing in a sample of cell phones in Denmark. Contact Dermatitis 2008; 59: 38-42.

4. Fors R, Persson M, Bergstr m E, et al. Nickel allergy - prevalence in a population of Swedish youths from patch test and questionnaire data. Contact Dermatitis 2008; 58: 80-7.

5. Lindberg M, Edman B, Fischer T, et al. Time trends in Swedish patch test data from 1992 to 2000. A multi-centre study based on age- and sex-adjusted results of the Swedish standard series. Contact Dermatitis 2007; 56: 205-10.

6. Fall S, Bruze M, Isaksson M, et al. Contact allergy trends in Sweden - a retrospective comparison of patch test data from 1992, 2000, and 2009. Contact Dermatitis 2015; 72: 297-304.

7. Garg S, Thyssen J P, Ulter W, et al. Nickel allergy following EU regulations in Denmark, Germany, Italy, and United Knigdom. Br J Dermal 2013; 169: 854-8.

8. Erfani B, Liden C, Midander K. Short and frequent skin contact with nickel. Contact Dermatitis 2015; 73: 222-30.

9. Thyssen JP, Jensen P, Lidén C, et al. Assessment of nickel and cobalt release from 200 unused hand-held work tools for sale in Denmark - sources of occupational metal contact dermatitis? Sci Total Environ 2011; 409: 4663-6.

10. Liden C. Nickel. In: Handbook of Occupational Dermatology. Kanerva L, Elsner P, Wahlberg J E, Maibach H I (eds). Springer-Verlag, Berlin. Heidelberg 2000; 524-33.

11. Meding B, Lantto R, Lindahl G, et al. Occupational skin disease in Sweden - a 12-year follow-up. Contact Dermatitis 2005; 53: 308-13.

12. Gollhausen R, Ring J. Allergy to coined money: nickel contact dermatitis in cashiers. J Am Acad Dermal 1991; 25: 365-9.
13. Liden C, Skare L, Vahter M. Release of nickel from coins and deposition onto skin from coin handling-comparing euro coins and SEK. Contact Dermatitis 2008; 50: 31-7.

14. Julander A, Midander K, Herting G, et al. New UK nickel-plated steel coins constitute an increased allergy and eczema risk. Contact Dermatitis 2013; 68: 323-30.

15. Numista. World coin catalog. http://en.numista.com.

16. International Contact Dermatitis Research Group. Revised European standard series. Contact Dermatitis 1988; 19: 391.

17. European Committee for Standardisation (CEN): EN 1811. Reference Test Method for Release of Nickel from Products Intended to Come into Direct and Prolonged Contact with the Skin. CEN, 1998.

18. Zhai H, Chew AL, Bashir SJ, et al. Contact dermatitis and allergy provocative use test of nickel coins in nickel-sensitized subjects and controls. Br J Dermatol 2003; 149: 311-7.

19. Darlenski R, Kazandjieva J, Pramatarov K. The many faces of nickel allergy. Int J Dermatol 2012; 51: 523-30.

20. Gawkrodger DJ, Lewis FM, Shah M. Contact sensitivity to nickel and other metals in jewelry reactors. J Am Acad Dermatol 2000; 43: 31-6.

21. Kanerva L, Estlander T, Jolanki R. Bank clerk's occupational allergic nickel and cobalt contact dermatitis from coins. Contact Dermatitis 1998; 38: 217-8.

22. Thyssen JP, Gawkrodger DJ, White IR, et al. Coin exposure may cause allergic nickel dermatitis: a review. Contact Dermatitis 2013; 68: 3-14.

23. Williams SP. Nickel dermatitis from coins. Contact Dermatitis 1999; 40: 60-1.

24. Hamann CR, Hamann D, Hamann C, et al. The cost of nickel allergy: a global investigation of coin composition and nickel and cobalt release. Contact Dermatitis 2013; 68: 15-22.

25. Fisher AA. Coin dermatitis. Cutis 1984; 33: 530-6.

26. Aberer W, Kranke B. The new EURO releases nickel and elicits contact eczema. Br J Dermatol 2002; 146: 155-6.

27. Lidén C, Carter S. Nickel release from coins. Contact Dermatitis 2001; 44: 160-5.

28. Lidén C, Skare L, Vahter M. Release of nickel from coins and deposition onto skin from coin handling - comparing euro coins and SEK. Contact Dermatitis 2008; 59: 31-7.

29. Staton I, Ma R, Evans N, et al. Dermal nickel exposure associated with coin handling and in various occupational settings: assessment using a newly developed finger immersion method. Br J Dermatol 2006; 154: 658-64.

30. Seidenari S, Giusti F, Pellacani G, et al. Reactivity to euro coins and sensitization thresholds in nickel-sensitive subjects. J Eur Acad Dermatol Venereol 2005; 19: 449-54.

31. Nucera E, Schiavino D, Calandrelli A, et al. Positive patch tests to Euro coins in nickel-sensitized patients. Br J Dermatol 2004; 15: 500-3.

32. Danish Environmental Protection Agency. Risk Assessment Targeted Report. Nickel as used in euro coins. Draft of June 1999. Danish Environmental Protection Agency, Copenhagen 1999.

33. Christensen O, Moller $\mathrm{H}$. External and internal exposure to the antigen in the hand eczema of nickel allergy. Contact Dermatitis 1975; 1: 136-41.

34. Meding B, Swanbeck G. Occupational hand eczema in an industrial city. Contact Dermatitis 1990; 22: 13-23.

35. Raanen L, Tuomi ML. Diagnostic value of the lymphocyte proliferation test in nickel contact allergy and provocation in occupational coin dermatitis. Contact Dermatitis 1992; 27: $250-4$ 
36. Allenby CF, Basketter DA. An arm immersion model of compromised skin (II). Influence on minimal eliciting patch test concentrations of nickel. Contact Dermatitis 1993; 28: 129-33.

37. Menné T. Quantitative aspects of nickel dermatitis. Sensitization and eliciting threshold concentrations. Sci Total Environ 1994; 148: 275-81.

38. Emmett EA, Risby TH, Jiang L, et al. Allergic contact dermatitis to nickel: bioavailability from consumer products and provocation threshold. J Am Acad Dermatol 1988; 19: 314-22.

39. Gawkrodger DJ, McLeod CW, Dobson K. Nickel skin levels in different occupations and an estimate of the threshold for reacting to a single open application of nickel in nickelallergic subjects. Br J Dermatol 2012; 166: 82-7.

40. Nestle FO, Speidel H, Speidel MO. Metallurgy: high nickel release from 1- and 2-euro coins. Nature 2002; 419: 132.

41. Josefson A, Farm G, Magnuson A, et al. Nickel allergy as risk factor for hand eczema: a population-based study. Br J Dermatol 2009; 160: 832-4.

42. Thyssen JP, Linneberg A, Menne T, et al. The association between hand eczema and nickel allergy has weakened among young women in the general population following the Danish nickel regulation: results from two cross-sectional studies. Contact Dermatitis 2009; 61: 342-8.

43. Thyssen JP, Johansen JD, Carlsen B, et al. Prevalence of nickel and cobalt allergy among female patients with dermatitis before and after Danish government regulation: a 23-year retrospective study. J Am Acad Dermatol 2009; 61: 799-805. 